\title{
NATURE VALUATION OF PLANT COMMUNITIES IN THE ZAGÓRÓW POLDER INCLUDING WATER CONTENT PARAMETERS*
}

\author{
Jan Kryszak, Anna Kryszak, Agnieszka Strychalska, CzesŁaw PrzybyŁa
}

\begin{abstract}
J. Kryszak, A. Kryszak, A. Strychalska, Department of Grassland and Natural Landscape Science, Poznań University of Life Science, Wojska Polskiego 38/42, 60-627 Poznań, Poland, e-mail: kryszak@up.poznan.pl Cz. Przybyła, Department of Land Improvement, Environmental Development and Geodesy, Poznań University of Life Science, Piątkowska 94, 60-649 Poznań, Poland, e-mail: czprzybyla@up.poznan.pl
\end{abstract}

(Received: January 9, 2014. Accepted: February 1, 2014)

\begin{abstract}
Geobotanical studies conducted in spring in 2011-2012 in the Zagórów polder washland, covered by the ecological restoration programme, provided assessment of current nature value of plant communities and indicated potential directions of their further transformations as a result of changes in habitat water content levels.

Based on the analyses of 77 relevés of $50-100 \mathrm{~m}^{2}$ each, prepared following the Braun-Blanquet method, water levels were assessed by phytoindication using moisture indicator values (F) according to ELLENBERG et al. (1992). Moreover, nature value of vegetation was assessed based on the botanical structure, geo-historical spectrum, life form structure as well as the nature valuation index in the 10-point scale according to Oświt (2000). Based on relevés the area was valuated using the point score method according to MAHON \& Miller (2003).

An attempt was made to indicate potential directions of changes in vegetation, based on the determination of dependencies between certain parameters assessing its current condition and habitat conditions. Habitat water content connected with the supply of water through a network of culverts, geomorphology of the area and land use, affects the distribution of phytocenoses in the polder and their considerable diversity, which was confirmed by the identification of 19 plant communities from six phytosociological classes. Further maintenance of water relations and land use results in the transformation of plant communities: in the vicinity of culverts - towards the class Phragmitetea, in swamps and around small water bodies - towards communities of the classes Salicetea purpurea or Alnetea glutinosae, at longer distances from culverts in leveled and agriculturally utilised areas - towards the orders Trifolio fragiferae-Agrostietalia stoloniferae and Molinietalia, while in areas at valley margins the succession progresses towards communities of the class Nardo-Callunetea.
\end{abstract}

KEY WORDS: plant communities, Warta river valley, moisture of site, synanthropisation, natural value

\section{INTRODUCTION}

Both agricultural activity and progressing urbanisation contribute to the destruction of natural habitats. In agricultural areas particularly drainage systems of valley soils, river regulation and inappropriate agricultural use have caused considerable and frequently irreversible changes in habitats (GRYNIA 1975, BARABASZ 1994, KuCHARSKi 1999, GrYNIA \& KRYSZAK 2001, BATOR 2005). The most disturbing phenomena are connected with the effects of anthropopressure in areas of nature value, located within the impact zone of river waters or open water bodies (RATYŃSKA \& SZWED 1999).

In the past the Warta river valley in its middle course served the role of an uncontrolled retention basin. Annual high water stages and the resulting flooding of agriculturally utilised areas caused considerable yield losses. These losses were reduced thanks to the construction of hydraulic water drainage structures, as well as construction of physical barriers separating the river channel from the rest of the valley and establishment of washland polders,

\footnotetext{
* Research work financed from the scientific budget resources in 2010-2012 as a research project No. NN 310381439.
} 
including the Zagórów polder (PrzyBYŁa et al. 2012, 2013). As a consequence, the varied vegetation cover of the riverbank areas, previously resultant both from the considerable habitat diversity and agricultural use, was transformed, partly comprising grassland (Brzeg 1989, Borysiak 1994, KRUPA 2000, 2002, KRYSZAK et al. 2001, 2006, RATYŃSKA 2001). However, in certain sections of the Warta among complexes of semi-natural vegetation we may still find areas of relatively well-preserved natural vegetation (BRZEG 1991 a, b, 1998). In turn, natural value may be restored in at least some of the transformed communities by regulation of water relations and appropriate water management, which will ensure preservation of areas of considerable nature value.

Since plant communities found in riverbank areas may be sensitive indicators of transformations occurring in the catchment, regular nature valuation of vegetation combined with monitoring of habitat changes and land use makes it possible not only to determine their current preservation status, but also indicate further potential directions of succession. Obtained information facilitates undertaking of practical measures, if need be, to protect existing communities (RATYŃSKA \& SZWED 1999).

The aim of the study was to assess current nature value of plant communities formed in the Zagórów polder, covered by the programme of ecological restoration of water relations, and to indicate potential directions of further transformations in plant communities as a result of changes in water relations.

\section{MATERIAL AND METHODS}

Geobotanical studies were conducted in spring in the years 2011-2012 in the Zagórów washland polder, where a network of culverts is used to aid water management (Fig. 1).

Detailed phytosociological studies were conducted in four transects delineated perpendicular to the flood embankment and running at a distance of $100 \mathrm{~m}$ as a $20 \mathrm{~m}$ belt along both sides of four culverts. A total of 77 relevés of $50-100 \mathrm{~m}^{2}$ each were taken in their area using the Braun-Blanquet method. Their botanical composition constituted the basis for the identification of plant communities following the current phytosociological system (MATUSZKIEWICZ 2008).

Water relation conditions were assessed by phytoindication using the moisture indicator values $(\mathrm{F})$ according to ElLENBERG et al. (1992).

Nature value of vegetation was determined based on the botanical composition, geo-historical spectrum, life form structure and nature valuation index in the 10-point scale by OśwIt (2000). Moreover,

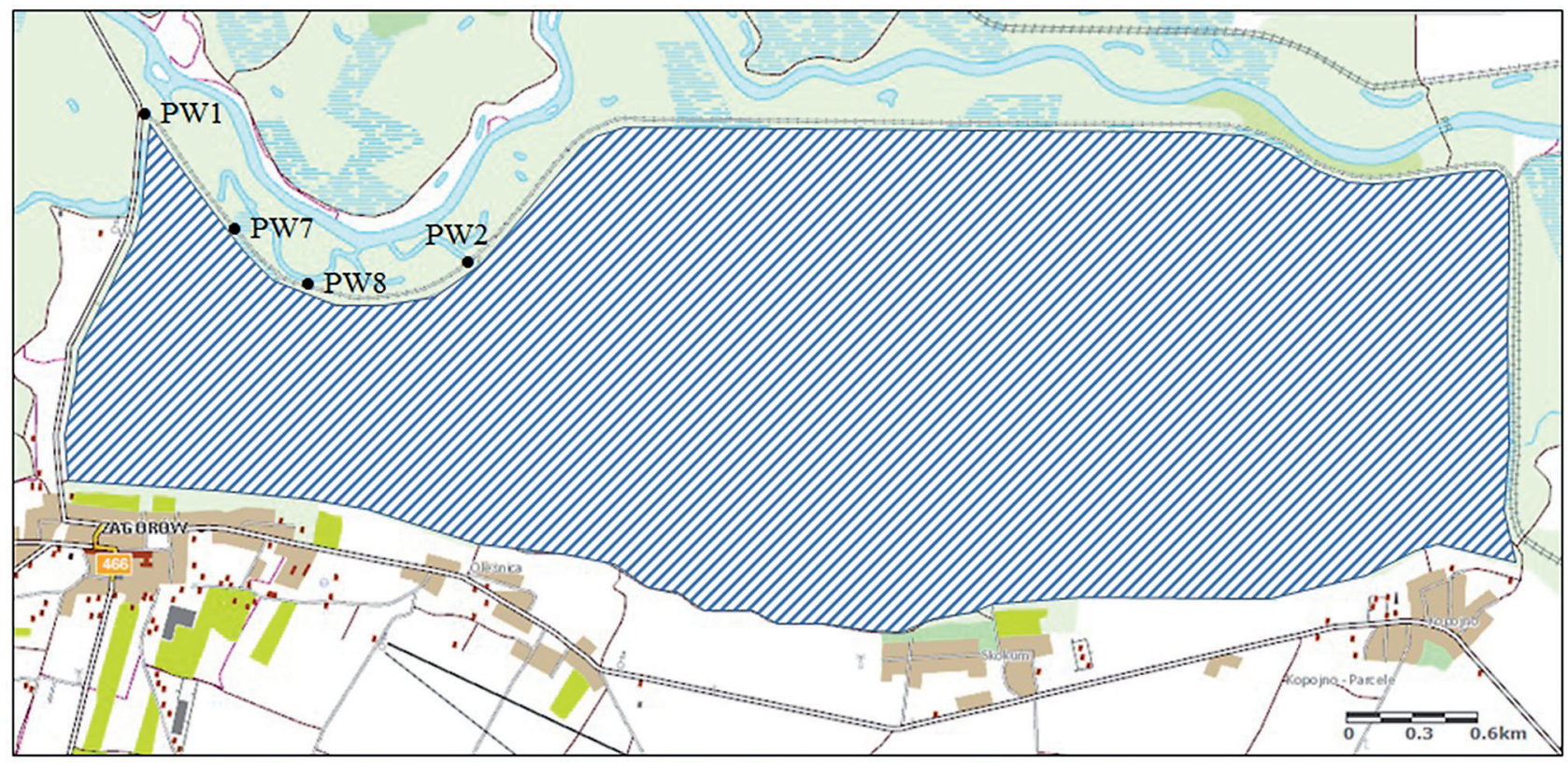

Zagórów polder

- PW1

- PW2

- PW7

culverts

- PW8

Fig. 1. The Zagórów polder (PrzyBYŁA et al. 2011) 
valuation was performed using relevés in the point score method developed by MAHON \& MiLleR (2003).

Nomenclature of plant species was adopted after MireK et al. (2002). Life forms were determined according to ZARZYCKI et al. (2002) as modified by JACKOWIAK (1993), while the geo-historical spectrum was presented following KornAś \& MEDWECKA-KORNAŚ (1986) as modified by JACKOWIAK (1993).

Based on the dependencies determined between certain parameters assessing the current vegetation condition and environmental conditions an attempt was made to indicate potential directions for its changes.

\section{RESULTS}

Habitat conditions in the Zagórów polder are varied, mainly in terms of water relations, which is connected with its changing surface features, geomorphology, as well as land use (Table 1). The above mentioned factors have resulted in a mosaic of habitats, which has also been promoted by the discharge of water through a network of culverts. They have facilitated water management and resulted in the initiation of restoration or formation of vegetation preferring moist habitats, particularly in the vicinity of culverts.

The greatest variation in habitat water content was observed in transects PW8 and PW2, which is manifested, among other things, in the structure and number of identified communities. In turn, the highest water content was recorded in habitats of transect PW7. Thus the greatest number of phytocenoses of Phragmitetea was reported in its area, followed by scrub communities of classes Salicetea purpureae and Alnetea glutinosae.

The shortest transects along culvert PW1 with periodically water-logged habitats are dominated by scrub communities of the class Salicetea purpureae. The next transects along PW2, PW7 and PW8 are longer, which results from the greater distance between the flood embankment and the valley margins based on the Zagórów-Ląd road. Those transects exhibit considerable variation in water contents, leading to a greater ecological mosaic of phytocenoses. Communities of the class Phragmitetea are found in the nearest vicinity of culverts. In turn, in agriculturally utilised areas communities of habitats with variable water contents predominate with an increase in the distance, representing mainly the orders Trifolio fragiferae-Agrostietalia stoloniferae and Molinietalia. Moreover, in transect PW8 communities of the class Nardo-Callunetea are found at the valley margin (Table 1).

Variation in water content of the polder habitats affected variation in vegetation. A total of 19 communities from 6 phytosociological classes were identified in the transects of the Zagórów polder. Most phytocenoses are connected with wet and
Table 1. Water contents in habitats of communities recorded at transects (assessed based on index F)

\begin{tabular}{|c|c|c|c|c|}
\hline No. of culvert & PW2 & PW8 & PW7 & PW1 \\
\hline Average of moisture content & 6.03 & 5.43 & 7.83 & 6.92 \\
\hline Min-max $H^{\prime}$ & $\begin{array}{l}2.48- \\
-9.91\end{array}$ & $\begin{array}{l}1.10- \\
-8.98\end{array}$ & $\begin{array}{l}4.67- \\
-9.87\end{array}$ & $\begin{array}{l}4.41- \\
-8.57\end{array}$ \\
\hline No. of communities & 7 & 9 & 10 & 3 \\
\hline No. of relevés & 16 & 24 & 32 & 5 \\
\hline No. of plant species & 72 & 64 & 91 & 52 \\
\hline \multicolumn{5}{|c|}{ Phragmitetea class } \\
\hline No. of relevés & 3 & 6 & 12 & - \\
\hline Acoretum calami & 9.91 & - & - & - \\
\hline Glycerietum maximae & - & 7.98 & - & - \\
\hline Sparganietum erecti & - & - & 9.87 & - \\
\hline Glycerietum fluitantis & 7.72 & - & - & - \\
\hline Caricetum gracilis & - & 7.80 & 8.53 & - \\
\hline Caricetum acutiformis & - & 8.98 & 8.90 & - \\
\hline Phalaridetum arundinaceae & - & 8.78 & 9.01 & - \\
\hline \multicolumn{5}{|c|}{ Salicetea purpureae class } \\
\hline No. of relevés & - & - & 3 & 1 \\
\hline Salicetum triandro-viminalis & - & - & 4.18 & - \\
\hline Salicetum albo-fragilis & - & - & 7.58 & 7.77 \\
\hline \multicolumn{5}{|c|}{ Alnetea glutinosae class } \\
\hline No. of relevés & - & - & 3 & 2 \\
\hline Salicetum pentrandro-cinerae & - & - & 8.66 & 8.57 \\
\hline com. with Alnus glutinosa & - & - & 7.95 & - \\
\hline \multicolumn{5}{|c|}{ Bidentetea tripartiti class } \\
\hline No. of relevés & - & - & 1 & - \\
\hline com. with Bidens tripartita & - & - & 8.90 & - \\
\hline \multicolumn{5}{|c|}{ Molinio-Arrhenatheretea class } \\
\hline No. of relevés & 12 & 9 & 13 & 2 \\
\hline com. with Festuca rubra & - & 4.89 & - & - \\
\hline com. Deschampsia caespitosa & 6.34 & 4.83 & - & - \\
\hline com. with Holcus lanatus & 5.67 & - & - & - \\
\hline Ranunculo-Alopecuretum geniculati & 4.73 & - & - & - \\
\hline $\begin{array}{l}\text { com. Agrostis stolonifera-Potentilla } \\
\text { anserina }\end{array}$ & 5.33 & 3.36 & 4.67 & 4.41 \\
\hline \multicolumn{5}{|c|}{ Nardo-Callunetea class } \\
\hline No. of relevés & 1 & 8 & - & - \\
\hline com. with Nardus stricta & - & 1.16 & - & - \\
\hline com. with Agrostis capillaris & 2.48 & 1.10 & - & - \\
\hline
\end{tabular}

moist habitats and they represent semi-natural and anthropogenic grass communities of the class Molinio-Arrhenatheretea. These are first of all syntaxa of periodically water-logged, extensively managed habitats from the orders Trifolio fragiferae-Agrostietalia stoloniferae and Molinietalia. Over 30\% relevés in the polder were classified to the community Agrostis stolonifera-Potentilla anserina (Table 1). In turn, periodically dried habitats in slightly elevated locations are occupied by the communities with Festuca rubra, with Holcus lanatus, with Nardus stricta and with Agrostis capillaris.

The conducted ecological restoration of water relations promotes the occurrence of phytocenoses from the class Phragmitetea represented here by seven plant associations. Among them the most frequently reported include Caricetum gracilis, Caricetum acutiformis and 
Phalaridetum arundinaceae, while communities from the class Salicetea purpureae are found in small patches. They are located in the vicinity of the embankment and in the initial sections of culverts, as well as in small swamps and around small water bodies.

Habitat variation has an effect on the number of species recorded in the transects as well as the identified communities. A total of 147 taxa of vascular plants were reported in the polder. The greatest number of species (91) was recorded in transect PW7, which habitats had moisture indicator values ranging from 4.67 to 9.87 and in the communities of Agrostis stolonifera-Potentilla anserina (87), Deschampsia caespitosa (55), as well as Caricetum gracilis and Phalaridetum arundinaceae (with 41 each, Table 2). A particularly high number of species in the phytocenoses of wet habitats, i.e. the class Phragmitetea, indicates that they represent transitional forms, which are transformed by the changing water relations (Table 2). Since it is the area in which moist habitats are being restored we need to assume that this is a slow process.

Native species predominate in the identified communities, mainly synanthropic species - apophytes. A particularly high percentage of non-synanthropic species was observed in phytocenoses from the class Phragmitetea, ranging from $25 \%$ in Acoretum calami to $41.7 \%$ in Sparganietum erecti, while it was as much as $44.4 \%$ in the Salicetum pentandro-cinereae willow scrub from the class Salicetea purpurae. This may be explained by the limited potential use dependent on groundwater level or the duration of flooding. In contrast, the lowest number of non-synanthropic species was recorded in extensively used phytocenoses with Festuca rubra (Table 2). Such a geo-historical spectrum is manifested, among other things, in nature value assessed according to Oświr (2000). The highest nature valuation indexes were calculated also for syntaxa from the class Phragmitetea, i.e. Glycerietum maximae, Sparganietum erecti, Caricetum acutiformis and a community from the class Bidentetea tripartitii - an association with Bidents tripartita. Values of the indexes classify them to valuation class VII defined by high nature value (Table 2).

Similarly, analysis of relevés using the point score method according to MAHON \& Miller (2003) showed that areas located the closest to culvert outflow abutments and in water-filled depressions exhibit the highest nature, aesthetic and recreational value (Fig. 2).

The positive effect on vegetation observed for water relations regulated by culverts is evidenced by its phytosociological structure, analysed both in transects and in communities.

The greatest number of species characteristic of phytosociological units both in wet and water-logged habitats was recorded in transects PW7 and PW1. This is reflected in values of moisture indicator $\mathrm{F}$ calculated for these transects (Fig. 3).

The effect of water content on the species composition of communities is evidenced by their phytosociological structure. This pertains particularly to

Table 2. Species richness, geo-historical spectrum and nature valuation of communities identified in the Zagórów polder

\begin{tabular}{|c|c|c|c|c|c|c|c|c|c|}
\hline \multirow[b]{2}{*}{ Community } & \multicolumn{2}{|c|}{$\begin{array}{c}\text { No. of plant } \\
\text { species }\end{array}$} & \multicolumn{4}{|c|}{ Geo-historical spectrum (\%) } & \multicolumn{3}{|c|}{ Nature valuation } \\
\hline & total & $\begin{array}{l}\text { in } \\
\text { relevé }\end{array}$ & $\begin{array}{l}\text { spon- } \\
\text { taneo- } \\
\text { phytes }\end{array}$ & $\begin{array}{l}\text { apo- } \\
\text { phytes }\end{array}$ & $\begin{array}{l}\text { archeo- } \\
\text { phytes }\end{array}$ & $\begin{array}{l}\text { keno- } \\
\text { phytes }\end{array}$ & $\begin{array}{l}\text { mean of } \\
\text { nature } \\
\text { valu- } \\
\text { ation } \\
\text { index }\end{array}$ & $\begin{array}{l}\text { valu- } \\
\text { ation } \\
\text { class }\end{array}$ & nature value \\
\hline Acoretum calami & 12 & 12 & 25.0 & 66.7 & - & 8.3 & 3.7 & VII & high \\
\hline Glycerietum maximae & 5 & 5 & 40.0 & 60.0 & - & - & 3.6 & VII & high \\
\hline Sparganietum erecti & 12 & 12 & 41.7 & 50.0 & - & 8.3 & 3.8 & VII & high \\
\hline Glycerietum fluitantis & 15 & 15 & 26.7 & 73.3 & - & - & 3.0 & $\mathrm{~V}$ & medium moderate \\
\hline Caricetum gracilis & 41 & 13.4 & 36.7 & 63.4 & - & - & 3.2 & VI & moderately high \\
\hline Caricetum acutiformis & 11 & 4.5 & 36.4 & 54.5 & - & 9.1 & 3.6 & VII & high \\
\hline Phalaridetum arundinaceae & 41 & 14.5 & 31.7 & 65.9 & - & 2.4 & 3.1 & VI & moderately high \\
\hline Salicetum triandro-viminalis & 15 & 15 & 20.0 & 80.0 & - & - & 3.1 & VI & moderately high \\
\hline Salicetum albo-fragilis & 35 & 12.7 & 25.7 & 68.6 & - & 5.7 & 2.6 & IV & moderate \\
\hline Salicetum pentrandro-cinerae & 28 & 13.3 & 44.4 & 50.0 & - & 5.6 & 3.2 & VI & moderately high \\
\hline Community with Alnus glutinosa & 18 & 18 & 5.6 & 94.4 & - & - & 2.4 & IV & moderate \\
\hline Community with Bidens tripartita & 7 & 7 & 28.6 & 57.1 & - & 14.6 & 3.7 & VII & high \\
\hline Community with Festuca rubra & 19 & 19 & 5.3 & 94.7 & - & - & 1.7 & II & moderately low \\
\hline Community Deschampsia caespitosa & 55 & 21.3 & 12.7 & 85.5 & 1.8 & - & 2.3 & IV & moderate \\
\hline Community with Holcus lanatus & 9 & 9 & - & 100.0 & - & - & 2.4 & IV & moderate \\
\hline Ranunculo-Alopecuretum geniculati & 20 & 30 & 20.0 & 76.7 & 3.3 & - & 2.9 & $\mathrm{~V}$ & medium moderate \\
\hline Community Agrostis stolonifera-Potentilla anserina & 87 & 14.4 & 28.7 & 63.2 & 4.6 & 3.6 & 2.8 & $\mathrm{~V}$ & medium moderate \\
\hline Community with Nardus stricta & 38 & 38 & 13.2 & 84.2 & 2.6 & - & 1.9 & III & low \\
\hline Community with Agrostis capillaris & 37 & 23.5 & 16.2 & 81.1 & 2.7 & - & 1.8 & II & moderately low \\
\hline
\end{tabular}



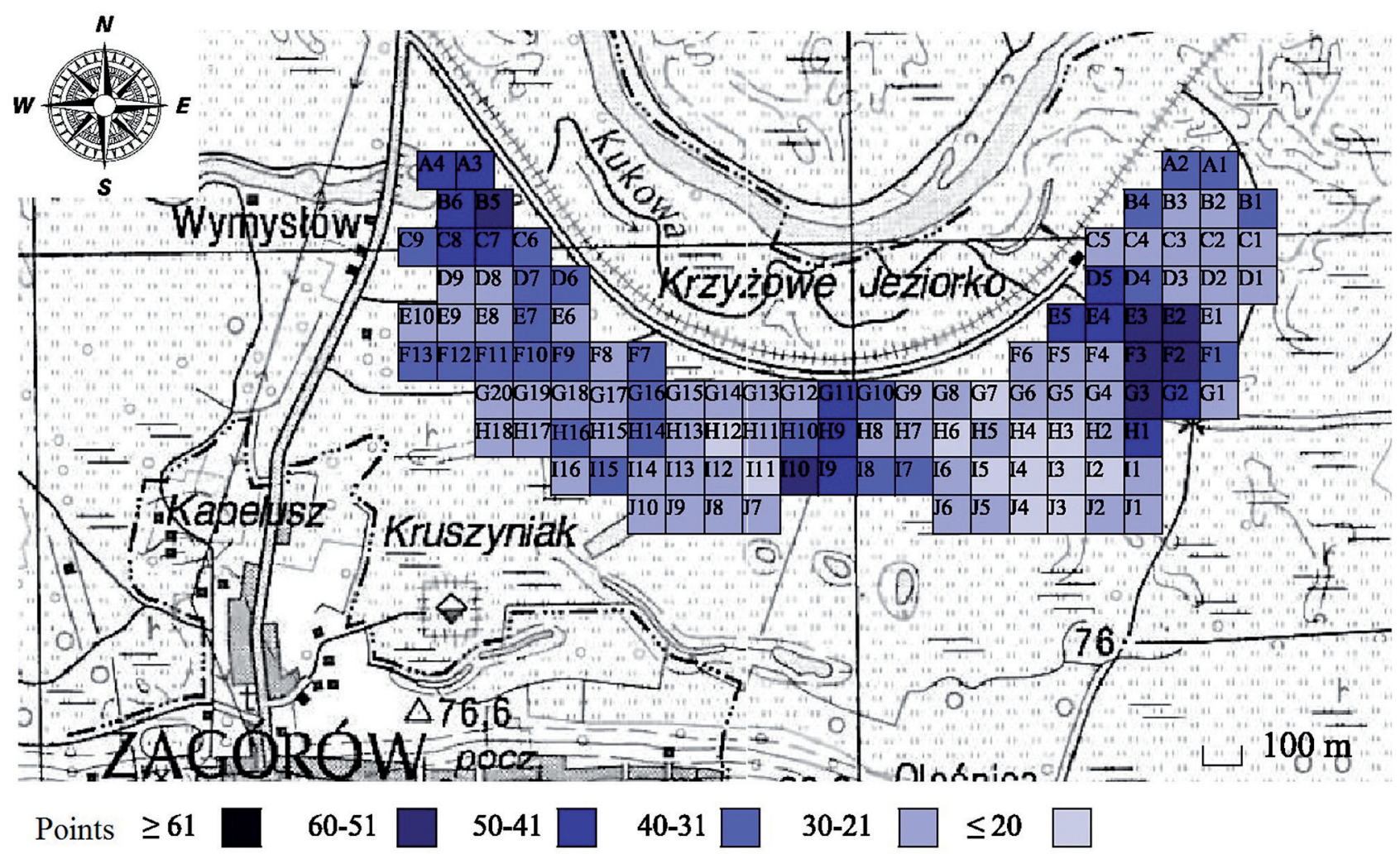

Fig. 2. Nature, aesthetic and recreational value of the Zagórów polder assessed according to MaHON \& MiLleR (2003)

grassland communities of the class Molinio-Arrhenatheretea. While most frequently they are well-developed phytocenoses with a high proportion of characteristic species, their species composition includes species of moist habitats, mainly from the class

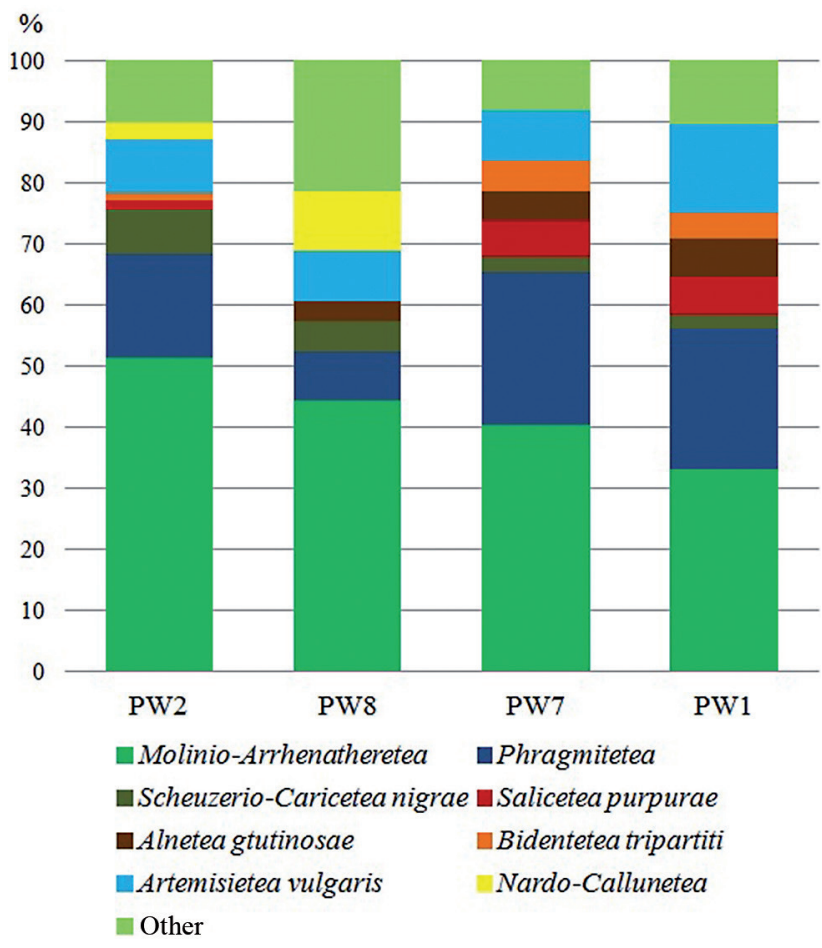

Fig. 3. Variation in phytosociological structure of vegetation in analysed transects $(\%)$
Phragmitetea, although most often found in stability classes I and II. This indicates a slow process of ecological restoration of water relations in this area. The effects of regulation of water relations in the polder are not observed in areas most distant from embankment culvert PW8, in elevated areas covered by phytocenoses representing the class Nardo-Callunetea. In turn, communities found in the vicinity of discharge culvert abutments are characterised by the greatest share of species characteristic of the classes Salicetea purpureae, Phragmitetea and Alnetea glutinosae, occasionally exceeding $70 \%$ (Table 3 ).

Summing up, in the Zagórów polder the distribution of phytocenoses, their phytosociological structure, as well as the geo-historical spectrum of syntaxa indicate a considerable dependence on habitat water content (Fig. 4). However, since this area is utilised agriculturally and many communities are of anthropogenic origin, the process of community restoration is very slow. They are exposed to continuous human interference and as a result their species composition most frequently comprises transition forms.

\section{DISCUSSION}

The vegetation cover of the Warta valley is diverse as a result of natural factors, such as high variability of the valley habitats, and anthropogenic factors connected first of all with agriculture, forestry and human settlements. Natural and semi-natural vegetation, frequently of high nature value, is found along 
Table 3. Phytosociological structure of identified communities (in \%)

\begin{tabular}{|c|c|c|c|c|c|c|c|c|c|}
\hline \multirow{2}{*}{ Community } & \multicolumn{9}{|c|}{ Diagnostic plant species for classes } \\
\hline & 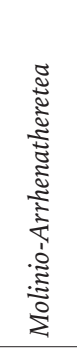 & 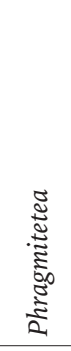 & 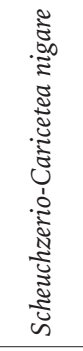 & 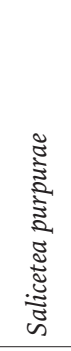 & 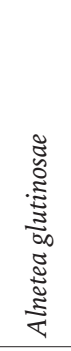 & 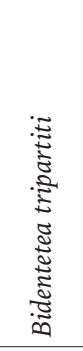 & 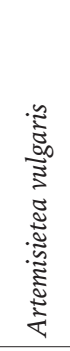 & 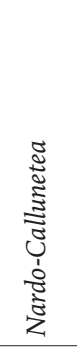 & $\begin{array}{l}\overrightarrow{ \pm} \\
\text { ज̃ }\end{array}$ \\
\hline Acoretum calami & 25.0 & 50.1 & - & - & - & - & 8.3 & - & 16.6 \\
\hline Glycerietum maximae & 40.0 & 40.0 & - & - & - & - & 20.0 & - & - \\
\hline Sparganietum erecti & - & 66.8 & - & - & 8.3 & 8.3 & 8.3 & - & 8.3 \\
\hline Glycerietum fluitantis & 60.0 & 20.0 & 13.3 & - & - & - & 6.7 & - & - \\
\hline Caricetum gracilis & 39.0 & 29.3 & 2.4 & - & 2.4 & 4.9 & 17.1 & - & 4.8 \\
\hline Caricetum acutiformis & 18.2 & 54.5 & - & - & - & 9.1 & 9.1 & - & 9.1 \\
\hline Phalaridetum arundinaceae & 36.6 & 34.2 & 2.4 & - & 4.9 & 7.3 & 9.8 & - & 4.8 \\
\hline Salicetum triandro-viminalis & 26.7 & 33.3 & - & 13.3 & - & 6.7 & 13.1 & - & 6.7 \\
\hline Salicetum albo-fragilis & 35.5 & 22.6 & - & 9.7 & 6.5 & 3.2 & 19.4 & - & 3.1 \\
\hline Salicetum pentrandro-cinerae & 22.2 & 37.1 & 3.7 & 3.7 & 11.1 & 7.4 & 11.1 & - & 3.7 \\
\hline Community with Alnus glutinosa & 47.1 & 11.8 & - & - & 5.9 & 17.6 & 17.6 & - & - \\
\hline Community with Bidens tripartita & 14.3 & 71.4 & - & - & - & 14.3 & - & - & - \\
\hline Community with Festuca rubra & 66.6 & - & - & - & 5.6 & - & 5.6 & 11.1 & 11.1 \\
\hline Community Deschampsia caespitosa & 54.7 & 5.7 & 7.5 & 1.9 & 1.9 & 1.9 & 9.4 & 5.7 & 11.3 \\
\hline Community with Holcus lanatus & 88.9 & - & - & - & - & - & 11.1 & - & - \\
\hline Ranunculo-Alopecuretum geniculati & 53.3 & 23.4 & 10.0 & - & - & - & 3.3 & - & 10.0 \\
\hline Community Agrostis stolonifera-Potentilla anserina & 44.4 & 23.5 & 6.2 & 2.5 & 3.7 & 3.7 & 6.2 & - & 9.8 \\
\hline Community with Nardus stricta & 47.2 & 5.5 & - & - & 2.8 & - & 8.3 & 13.9 & 22.2 \\
\hline Community with Agrostis capillaris & 52.9 & - & - & - & - & - & 11.8 & 11.9 & 23.4 \\
\hline
\end{tabular}

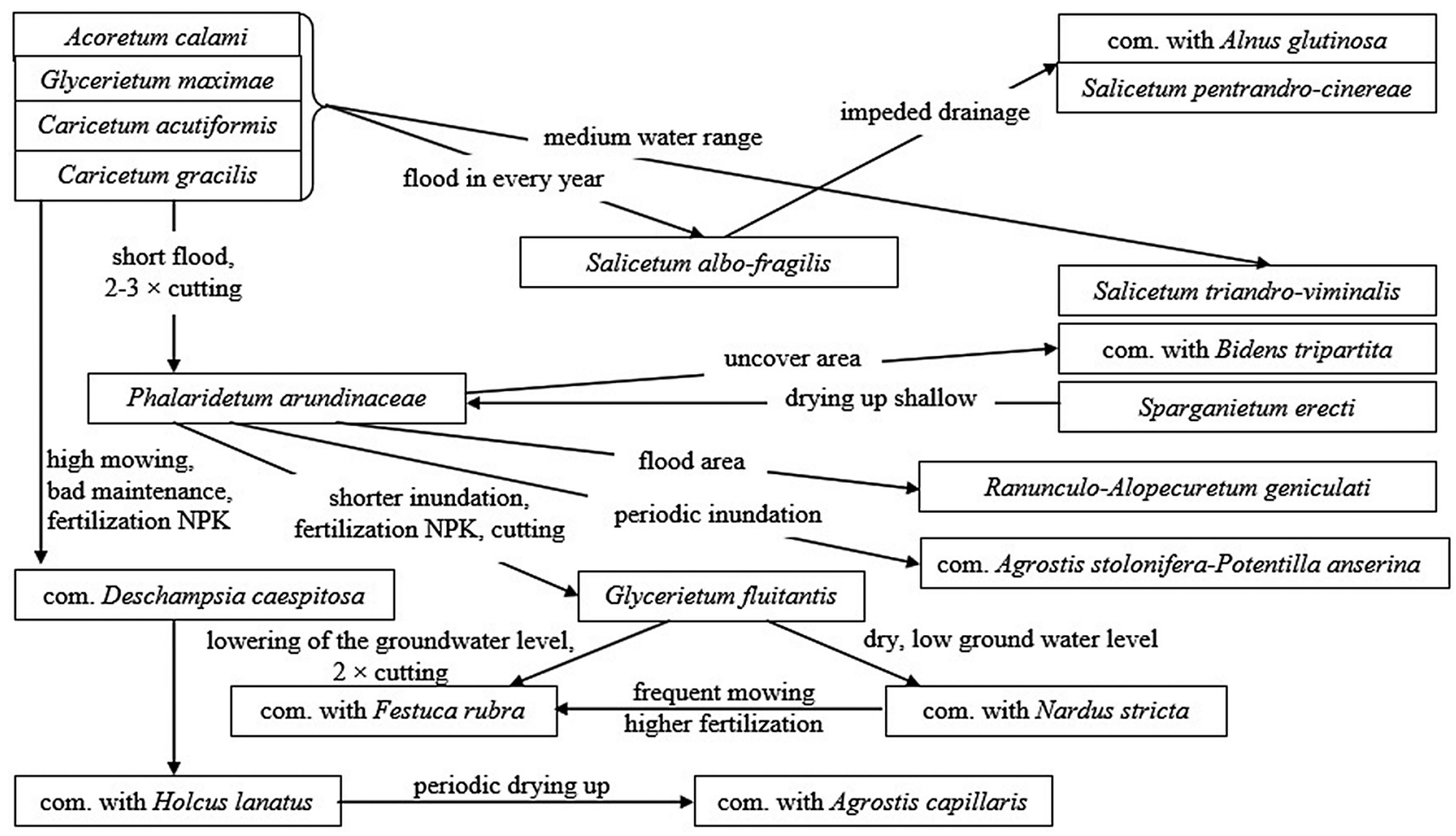

Fig. 4. Directions of succession in the Zagórów polder 
the river. However, apart from riverside and marshy phytocenoses adjacent to the river the Warta washlands are also covered by extensive non-rush meadow and pasture phytocenoses and it is the latter that are at the greatest threat of transformation (BORYSIAK 1994). Particularly the construction of the Jeziorsko retention reservoir and performed drainage operations contributed to considerable changes in vegetation in the middle section of the Warta valley. Drainage operations accelerated the rate of changes in habitat conditions, mainly water levels in meadow habitats (GrYNIA 1975, Barabasz 1994, Kostuch 1995, KuCHARski 1999). An example may be provided by the Konin-Pyzdry section of the Warta valley (KRUPA 2000, 2002). However, the recorded results indicate a dependence of the species composition of communities on habitat water content and thus confirm the potential to stop further drainage of the Warta valley or even to gradually restore water conditions in its certain sections owing to restoration of water relations. Both the distribution of communities in the transects in relation to culverts and their phytosociological structure confirm effectiveness of the operation of hydraulic and drainage infrastructure in restoration of nature value to this section of the Warta valley. Particularly in the transects comprising habitats with higher water contents a greater share of phytocenoses from the classes Phragmitetea and Salicetea purpurea was found, while the others representing other classes comprised a considerable percentage of species characteristic of units in wet and water-logged habitats.

Next to habitat conditions, species composition of communities found in the polder is greatly affected by land use. In water-logged areas it is dependent on current water conditions, thus most frequently it is extensive land use. It is manifested in the dominance of native species, among which a considerable proportion is found for non-synanthropic species. As it was reported by Grynia (1975), BARABASZ (1994), KoSTUCH (1995) and KUCHARSKI (1999), both the adopted grassland management measures and the conditions found in a given area are reflected in the species composition of multi-species grass phytocenoses.

In conclusion, transformations of vegetation in the Zagórów polder, as it is confirmed by results reported by other authors (KoRNAś 1983, LOSVIK 1988, Kornaś \& Dubiel 1991, Barabasz 1994, Bator 2005, KozŁowsKA 2005), are caused by modifications in grassland management and by habitat conditions. Thus development of an appropriate natural management plan for the Warta washlands will facilitate the implementation of spatial order and result in the preservation of functions and characteristics of valley ecosystems. As a consequence, research focused on the characterisation of communities and valuation of their nature aspects makes it possible to indicate the direction of changes they are undergoing, define their cause and on this basis ensure their sustainable management.

\section{CONCLUSIONS}

1. The habitat mosaic of the Zagórów polder, which among other things is a consequence of water management, i.e. its discharge through a network of culverts, results in a considerable variation of the vegetation cover, which is confirmed by phytosociological analysis and identification of plant 19 communities from six phytosociological classes.

2. Distribution of phytocenoses in the polder, their phytosociological structure, geo-historical spectrum and nature value depend first of all on water relations, which is confirmed by:

- their phytosociological structure - the greatest share of species characteristic of the class Phragmitetea was found in syntaxa of habitats found in the nearest vicinity of embankment culverts and depressions,

- the geo-historical spectrum of communities - the greatest number of non-synanthropic species was recorded in communities formed in very wet, sporadically used habitats with variable water contents, i.e. Sparganietum erecti, Salicetum pentandro-cinereae,

- nature value of communities - the highest, high or moderately high values (valuation classes VII-VI) are recorded for communities in the habitats with the highest water contents.

3. Analysis of results of floristic and habitat studies indicates that at the maintenance of water conditions and management the changes will occur:

- in the vicinity of culverts - towards communities of the class Phragmitetea,

- in swamps and around small water bodies - towards communities of the classes Salicetea purpurea or Alnetea glutinosae,

- $\quad$ at greater distances from culverts in levelled and agriculturally utilised areas - towards alliances of the orders Trifolio fragiferae-Agrostietalia stoloniferae and Molinietalia

- in the valley margins succession progresses towards communities of the class Nardo-Callunetea.

\section{REFERENCES}

Barabasz B. (1994): Wpływ modyfikacji tradycyjnych metod gospodarowania na przemiany roślinności łąk z klasy Molinio-Arrhenatheretea. Wiadomości Botaniczne 38(1-2): 85-94.

BATOR I. (2005): Stan obecny i przemiany zbiorowisk łąkowych okolic Mogilan (Pogórze Wielickie) w okresie 40 lat. Fragmenta Floristica et Geobotanica Polonica, Supplementum 7: 1-97 
BoRYSIAK J. (1994): Struktura aluwialnej roślinności lądowej środkowego i dolnego biegu Warty. Wydawnictwo UAM, Poznań.

BRzEG A. (1989): Zbiorowiska łąkowe i pastwiskowe okolic Konina. Poznańskie Towarzystwo Przyjaciół Nauk, Wydział Matematyczno-Przyrodniczy, Prace Komisji Biologicznej 70: 103-139.

Brzeg A. (1991 a): Inwentaryzacja geobotaniczna gminy Pyzdry. Typescript. Oprac. dla Wydziału Ochrony Środowiska i Gospodarki Wodnej UW w Koninie. Poznań.

BRzeG A (1991 b): Inwentaryzacja geobotaniczna gminy Zagórów. Typescript. Oprac. dla Wydziału Ochrony Srodowiska i Gospodarki Wodnej UW w Koninie. Poznań.

BRzeG A. (1998): Geobotaniczna charakterystyka projektowanego rezerwatu częściowego „Łąki Pyzderskie" w Nadwarciańskim Parku Krajobrazowym. Rocznik Naukowy Polskiego Towarzystwa Ochrony Przyrody „Salamandra” 2: 5-37.

Ellenberg H., Weber H.E., Düll R., Wirth V., Werner W., Paulissen D. (1992): Zeigerwerte von Pflanzen in Mitteleuropa. Scripta Geobotanica 18.

Grynia M. (1975): Przekształcenia się zbiorowisk łąkowo-pastwiskowych w ostatnich dziesiątkach lat, jako wskaźnik zmian w środowisku przyrodniczo-rolniczym. Zeszyty Problemowe Postępów Nauk Rolniczych 169: 31-40.

GrYNIA M., KRYSZAK A. (2001): Najczęstsze przyczyny zmian ekosystemów łąkowych. Zeszyty Naukowe AR w Krakowie 382, Inżynieria Środowiska 21: 593-600.

JACKOWIAK B. (1993): Atlas rozmieszczenia roślin naczyniowych w Poznaniu (Atlas of distribution of vascular plants in Poznań). Prace Zakładu Taksonomii Roślin UAM w Poznaniu 2.

KornAŚ J. (1983): Oddziaływanie człowieka na florę; mechanizmy i konsekwencje. Wiadomości Botaniczne 25: 165-182.

Kornaś J., Dubiel E. (1991): Land use and vegetation changes in hay-meadow in the Ojców National Park during last thirty years. Veröf. Geobot. Inst. ETH, Stiftung Rübel, Zurich, 106: 209-231.

Kornaś J., Medwecka-Kornaś A. (1986): Geografia roślin. PWN, Warszawa.

Kostuch R. (1995): Przyczyny występowania różnorodności florystycznej ekosystemów trawiastych. In: Różnorodność florystyczna użytków zielonych. Annales Universitatis Mariae Curie-Skłodowska 50, sectio E: 23-32.

KozŁowsKA T. (2005): Zmiany zbiorowisk łąkowych na tle różnicowania się warunków siedliskowych $\mathrm{w}$ charakterystycznych obszarach dolin rzecznych Polski Centralnej. Woda - Środowisko - Obszary Wiejskie. Rozprawy naukowe i monografie 14 .

KRUPA K. (2000): Zbiorowiska szuwarowe okolic Lądka w Nadwarciańskim Parku Krajobrazowym.
Rocznik Naukowy Polskiego Towarzystwa Ochrony Przyrody „Salamandra” 4: 25-53.

KRUPA K. (2002): Zbiorowiska roślinne z klasy Molinio-Arrhenatheretea R.Tx. 1937 em. 1970 okolic Lądka w Nadwarciańskim Parku Krajobrazowym. Rocznik Naukowy Polskiego Towarzystwa Ochrony Przyrody „Salamandra” 6: 5-27.

Kryszak A., Grynia M., BudzińsKi M. (2001): Zbiorowiska ląkowe terasy zalewowej doliny Warty w okolicach Konina. PTPN, Prace Komisji Nauk Rolniczych i Komisji Nauk Leśnych 91: 67-76.

Kryszak A., Kryszak J., Grynia M. (2006): Zróżnicowanie geomorfologiczne terenów zalewanych doliny Warty a występowanie zbiorowisk łąkowo-szuwarowych. Annales Universitatis Mariae Curie-Skłodowska 61, sectio E: 285-292.

KuCHARSKi L. (1999): Szata roślinna łąk Polski środkowej i jej zmiany w XX wieku. Wydawnictwo Uniwersytetu Łódzkiego, Łódź.

Losvik M.H. (1988): Phytosociology and ecology of old hay meadow in Hordaland, western Norway in relation to management. Vegetation 78: 157-187.

Mahon J.R., Miller R.W. (2003): Identifying high-value greenspace prior to land development. Journal of Arboriculture 29(1): 25-33.

Matuszkiewicz W. (2008): Przewodnik do oznaczania zbiorowisk roślinnych Polski. Wyd. Nauk. PWN, Warszawa.

Mirek Z., Pięroś-Mirkowa H., Zając A., Zając M. (2002): Flowering plants and pteridophytes of Poland. A checklist. Vol. 1. Biodiversity of Poland. - Krytyczna lista roślin naczyniowych Polski. T. 1. Różnorodność biologiczna Polski. W. Szafer Institute of Botany, Polish Academy of Sciences, Kraków.

Oświt J. (2000): Metoda przyrodniczej waloryzacji mokradeł i wyniki jej zastosowania na wybranych obiektach. Instytut Melioracji i Użytków Zielonych, Materiały Informacyjne 35.

Przybyea Cz., Bykowski J., Mrozik K., Napierała M. (2011): Znaczenie polderu Zagórów w ochronie przeciwpowodziowej. Rocznik Ochrona Środowiska 13: 801-814.

Przybyea Cz., Malinger A., Mrozik K. (2012): Wpływ budowli hydrotechnicznych na renaturyzację gospodarki wodnej Polderu Zagórów. Rocznik Ochrona Środowiska (Annual Set the Environment Protection) 14: 351-369.

Przybyea Cz., Napierała M., Bykowski J., Mrozik K. (2013): Polder Zagórów przykładem renaturyzacji gospodarki wodnej. In: T. Kałuża (eds). Hydrauliczne i hydrograficzne aspekty powodzi w 2010 roku w zlewni Wisły i Odry. Bogucki Wyd. Nauk., Poznań: 73-81.

Ratyńska H. (2001): Roślinność Poznańskiego Przełomu Warty i jej antropogeniczne przemiany. Akademia Bydgoska im. Kazimierza Wielkiego, Bydgoszcz. 
RATYŃSKA H., SzWEd W. (1999): Waloryzacja przyrodnicza oraz wskazania ochronne dla terasy zalewowej Warty w parkach krajobrazowych środkowej Warty. Biuletyn Parków Krajobrazowych Wielkopolski 4(6): 1-115.

ZarZYCKi K., TRZCiŃSKa-TACiK H., RóżańSKi W., SZELĄG Z., WołeK J., Korzeniak U. (2002): Ecologi- cal indicator values of vascular plant of Poland. Vol. 2. Biodiversity of Poland. - Ekologiczne liczby wskaźnikowe roślin naczyniowych Polski. T. 2. Różnorodność biologiczna Polski. W. Szafer Institute of Botany, Polish Academy of Sciences, Kraków. 